\title{
Penerapan Pelayanan Kesehatan \\ Masyarakat Miskin Yang Ideal \\ Dalam Pelayanan Kesehatan Masyarakat Miskin Melalui Program Jamkesmas
}

\author{
Anthony Sudjadi, Agnes Widanti, Y. Budi Sarwo dan Handy Sobandi \\ Anthony_sudjadi@gmail.com \\ Magister Hukum Kesehatan \\ Universitas Katolik Soegijapranata Semarang
}

\begin{abstract}
ABSTRAK
Berdasarkan Undang-Undang Dasar 1945 Pasal 28H dan UU Nomor 36 Tahun 2009 tentang kesehatan, menetapkan bahwa setiap orang berhak mendapatkan pelayanan kesehatan. Jamkesmas adalah program bantuan sosial untuk pelayanan kesehatan bagi masyarakat miskin dan tidak mampu. Namun terdapat pembatasan dan pelayanan yang tidak ditanggung dalam program tersebut yang berdampak warga miskin menjadi rentan terhadap berbagai macam penyakit

Berdasarkan uraian tersebut, maka dalam penelitian tesis ini dirumuskan beberapa perumusan masalah, yaitu "Apakah yang dimaksud dengan kriteria pelayanan kesehatan yang ideal?" dan "Apakah yang dimaksud dengan program Jamkesmas dan isi program tersebut?", serta "Apakah program Jamkesmas tersebut menyebabkan dilanggarnya hak masyarakat untuk mendapat upaya kesehatan yang ideal?". Penelitian tesis ini bertujuan untuk mendapatkan gambaran mengenai hubungan antara pelayanan kesehatan masyarakat miskin melalui program Jamkesmas dan pelayanan kesehatan kepada masyarakat miskin yang ideal, dengan metode penelitian pendekatan yuridis normatif dengan cara berpikir deduktif dan spesifikasi penelitian deskriptif analitis, serta metode analisis data kualitatif normatif.

Kriteria upaya kesehatan yang ideal berdasarkan UU kesehatan nomor 36 tahun 2008 pasal 47 adalah meliputi perlindungan di bidang promotif, prefentif, kuratif, dan rehabilitative.

Terdapat pembatasan-pembatasan dalam pelayanan dari program Jamkesmas berdasarkan Keputusan Menteri Kesehatan Nomor 125/Menkes/SK/II/2008 seperti pembatasan biaya kaca mata, alat bantu dengar, tongkat/alat bantu berjalan bagi mereka yang lumpuh, selain itu program jamkesmas tidak meliputi bidang promotif dan preventif serta terdapat pembatasan pelayanan di bidang kuratif dan rehabilitatif.

Berdasarkan analisis hubungan antara kriteria upaya kesehatan yang ideal berdasarkan UU Kesehatan nomor 36 tahun 2009 pasal 47 dan isi dari program Jamkesmas maka menyebabkan dilanggarnya hak masyarakat miskin untuk hidup sehat.
\end{abstract}

Kata kunci : kesehatan, Jamkesmas, ideal, pembatasan 


\section{PENDAHULUAN}

\section{A. Latar Belakang Penelitian}

Undang-Undang Dasar 1945 Pasal 28H dan Undang-Undang Nomor 36 Tahun 2009 tentang Kesehatan, menetapkan bahwa setiap orang berhak mendapatkan pelayanan kesehatan. Karena itu setiap individu, keluarga dan masyarakat berhak memperoleh perlindungan terhadap kesehatannya, dan negara bertanggungjawab mengatur agar terpenuhi hak hidup sehat bagi penduduknya, termasuk bagi masyarakat miskin dan tidak mampu.

Pembentukan Sistem Jaminan Sosial Nasional, direalisasikan melalui Undang-Undang Nomor 40 Tahun 2004 tentang Sistem Jaminan Sosial Nasional (UU SJSN) yang mempunyai program jaminan kesehatan, jaminan kecelakaan kerja, jaminan hari tua, jaminan pensiun dan jaminan kematian. Jaminan sosial ini merupakan upaya pemerintah dalam menangani krisis moneter.

Untuk dapat melanjutkan hidupnya manusia memerlukan beberapa kebutuhan pokok dan terdapat beberapa kebutuhan pokok yang minimal sangat dibutuhkan sehingga manusia dapat hidup terus. Salah satu di antara kebutuhan yang dimaksud adalah kesehatan.

Kebutuhan pokok minimal yang semakin sulit didapat bagi sebagian warga, terutama warga miskin, harus diupayakan dicapai oleh pemerintah dengan berbagai cara. Salah satu upaya yakni dengan program asuransi sosial bagi masyarakat miskin. Dalam program ini masyarakat miskin akan didata terlebih dahulu degan beberapa kriteria yang telah ditentukan sebelumnya agar terdapat keseragaman dalam melaksanakan pendataan tersebut. Pada pelaksanaannya pendataan yang dihasilkan tidak seperti yang diharapkan sebelumnya karena berbagai kendala. Kendala yang dimaksud antara lain kriteria yang menjadi acuan tidak terlalu jelas batasan yang menjadi acuan bagi para pendata, sehingga terkesan pendataannya seperti tidak tepat sasaran. Selain itu kondisi geografi yang tidak sama antara satu daerah dengan daerah lainnya. Ada daerah yang sulit untuk dijangkau sehingga pendataan tidak sampai sasaran. Faktor ekonomi yang tidak kunjung membaik, hal ini tampak dari laporan Bank Dunia yang memperhitungkan 108,78 juta orang atau 49 persen dari total penduduk Indonesia dalam kondisi miskin dan rentan menjadi miskin.

Sehat menurut definisi Undang-Undang Nomor 23 Tahun 1992 tentang Kesehatan Pasal 1 butir 1 adalah keadaan sejahtera dari badan, jiwa, sosial yang memungkinkan setiap orang dapat hidup produktif secara sosial dan ekonomi.

Untuk mendapatkan asuransi kesehatan bagi masyarakat miskin ada beberapa syarat atau kriteria yang harus dipenuhi, namun perlu juga dikemukakan di sini bahwa ada pelayanan kesehatan yang tidak ditanggung oleh PT Askes, seperti untuk general check up, prothesis gigi tiruan, kosmetika, pengobatan alternative, penunjang diagnosa canggih, kecuali untuk penyelamatan jiwa (life saving), serta infertilitas.

Adanya keterbatasan pelayanan kesehatan membawa dampak bagi warga miskin yakni rentan terhadap berbagai macam penyakit, karena pada umumnya golongan masyarakat ini mempunyai gizi buruk, pengetahuan tentang kesehatan kurang, perilaku kesehatan kurang, lingkungan pemukiman buruk, biaya kesehatan tidak tersedia serta kurang mendapat akses informasi kesehatan.

Jamkesmas adalah program bantuan sosial untuk pelayanan kesehatan bagi masyarakat miskin dan tidak mampu. Program ini diselenggarakan secara nasional agar terjadi subsidi silang dalam rangka mewujudkan pelayanan kesehatan yang menyeluruh bagi masyarakat miskin.

Adanya pembatasan-pembatasan pelayanan yang diterapkan dalam penyelenggaraan program JPKMM ini (misalnya pembatasan biaya kaca mata, alat bantu dengar, tongkat/alat bantu berjalan bagi mereka yang lumpuh) menyebabkan pelayanan kepada mereka yang 
membutuhkan sekali alat bantu tersebut menjadi terhambat. Disamping pembatasan masih ada lagi jenis pelayanan yang tidak ditanggung sama sekali oleh program Jamkesmas ini sebagaimana tercantum dalam S.K. Menkes No. 125 Tahun 2008 tentang Pedoman Pelaksanaan Program Jamkesmas Tahun 2008 tersebut.

Program JAMKESMAS ini sebenarnya cukup baik tujuannya namun dalam pelaksanaannya tidak semua masyarakat miskin dapat merasakan manfaatnya karena keterbatasan dana pemerintah sehingga pemerintah menetapkan kuota tertentu untuk perlindungan masyarakat miskin yang dibiayai dari APBN, sedangkan sisanya yang tidka termasuk dalam kuota JAMKESMAS diserahkan ke pemerintah daerah setempat untuk ditanggulangi oleh dana yang berasal dari APBD masing-masing daerah.

\section{B. Perumusan Masalah}

Dari latar belakang masalah di atas dapat dirumuskan masalah sebagai berikut: Apakah adanya ketentuan tentang pembatasan pelayanan kesehatan bagi warga miskin melanggar Undang Undang Nomor 23 Tahun 1992 Tentang Kesehatan? Karena tidak semua sarana pelayanan kesehatan dapat digunakan oleh masyarakat miskin, kecuali keadaan gawat darurat (emergency) serta adanya ketentuan pelayanan kesehatan yang di batasi dan yang tidak di jamin. Pada dasarnya setiap warga Negara baik yang kaya atau yang miskin mempunyai hak yang sama dalam memperoleh pelayanan kesehatannya, sehingga dari hal hal yang melatar belakangi permasalahan kesehatan bagi warga miskin tersebut dapat dibuat identifikasi masalah yakni:

1. Bagaimana wujud pelayanan kesehatan masyarakat miskin yang ideal?

2. Bagaimana hubungan pelayanan kesehatan masyarakat miskin melalui program JAMKESMAS dan pelayanan kesehatan masyarakat miskin yang ideal?

\section{METODE PENELITIAN}

\section{A. Metode Pendekatan}

Metode pendekatan yang digunakan dalam penelitian tesis ini, yaitu yuridis normatif. Yang dimaksud dengan metode pendekatan yuridis normatif, yaitu suatu cara meneliti dalam penelitian hukum yang dilakukan terhadap bahan pustaka atau data sekunder belaka dan dengan menggunakan metode berpikir deduktif serta kriterium kebenaran koheren. ${ }^{1}$

Selanjutnya menurut Sedarmayanti \& Syarifudin Hidayat, yang dimaksud dengan metode berpikir deduktif adalah:

"Cara berpikir dalam penarikan kesimpulan yang ditarik dari sesuatu yang sifatnya umum yang sudah dibuktikan bahwa dia benar dan kesimpulan itu ditujukan untuk sesuatu yang sifatnya khusus."

Sedangkan yang dimaksud dengan kebenaran koheren (the coherence theory of truth), menurut A. Sonny Keraf \& Mikhael Dua, adalah:

"Suatu pengetahuan, teori, pernyataan, proposisi, atau hipotesis dianggap benar kalau sejalan dengan pengetahuan, teori, pernyataan, proposisi, atau hipotesis lainnya, yaitu

\footnotetext{
${ }^{1}$ Lihat Wila Chandrawila Supriadi, Metode Penelitian (tidak dipublikasikan) dalam Materi Kuliah "Metode Penelitian Hukum" Program Pascasarjana Program Studi Magister Hukum Kesehatan Unika Soegijapranata, Semarang, 2006, hlm. 8.

${ }^{2}$ Sedarmayanti \& Syarifudin Hidayat, MetodologiPenelitian, Mandar Maju, Bandung, 2002, hlm. 23.
} 
kalau proposisi itu meneguhkan dan konsisten dengan proposisi sebelumnya yang dianggap benar."3

\section{B. Spesifikasi Penelitian}

Dalam penelitian ini, spesifikasi penelitian yang digunakan adalah deskriptif analitis. Menurut Moh. Nazir, yang dimaksud dengan deskriptif analitis, yaitu:

"Membuat deskripsi atau gambaran secara sistematis, faktual dan akurat mengenai fakta, sifat dan hubungan antar fenomena atau gejala yang diteliti sambil menganalisisnya, yaitu mencari sebab akibat dari suatu hal dan menguraikannya secara konsisten dan sistematis serta logis." 4

Selanjutnya, spesifikasi penelitian deskriptif analitis ini digunakan untuk menganalisis, yaitu mencari sebab akibat dari permasalahan yang terdapat pada perumusan masalah dan menguraikannya secara konsisten, sistematis dan logis sesuai dengan perumusan masalah yang menjadi fokus dalam penelitian ini, yaitu penerapan asas kebebasan berkontrak pada persetujuan tindakan kedokteran antara dokter dan pasien dalam suatu transaksi terapeutik.

\section{Jenis Data}

Jenis data yang dipergunakan dalam penelitian ini, yaitu data sekunder. Menurut Hilman Hadikusuma, yang dimaksud dengan data sekunder yaitu:

"Data yang diperoleh peneliti dari penelitian kepustakaan dan dokumentasi, yang merupakan hasil penelitian dan pengolahan orang lain, yang sudah tersedia dalam bentuk buku-buku atau dokumentasi yang biasanya disediakan di perpustakaan umum atau perpustakaan milik pribadi." ${ }^{5}$

Di dalam penelitian hukum, menurut Soerjono Soekanto \& Sri Mamudji data sekunder tersebut meliputi: "bahan hukum primer, bahan hukum sekunder, dan bahan hukum tertier". ${ }^{6}$ Bahan hukum primer adalah bahan hukum yang terdapat dalam suatu aturan hukum atau teks otoritatif, seperti peraturan perundang-undangan, putusan hakim, traktat, kontrak, keputusan tata usaha negara. Bahan hukum primer yang dipergunakan dalam penelitian ini terdiri dari peraturan perundang-undangan, misalnya UUD 1945, Undang Undang Nomor 23 Tahun 1992 tentang Kesehatan dan UU No.40/2004 tentangSJSN, beserta peratuan pelaksanaannya.

Sedangkan bahan hukum sekunder adalah bahan hukum yang diperoleh dari buku teks, jurnal-jurnal asing, pendapat para sarjana, kasus-kasus hukum, serta simposium yang dilakukan para pakar hukum mengenai asas kebebasan berkontrak dan persetujuan tindakan kedokteran antara dokter dan pasien dalam suatu transaksi terapeutik. Selain itu, dalam penelitian ini dipergunakan pula bahan hukum tersier. Bahan hukum tersier adalah bahan hukum yang memberikan petunjuk atau penjelasan bermakna terhadap bahan hukum primer dan sekunder, seperti kamus hukum, ensiklopedia, dan lain-lain.

\footnotetext{
${ }^{3}$ A. Sonny Keraf \& Mikhael Dua, Ilmu Pengetahuan (Sebuah Tinjauan Filosofis), Kanisius, Yogyakarta, 2001, hlm. 68.

${ }^{4}$ Lihat Moh. Nazir, Metode Penelitian, Ghlm.ia Indonesia, Jakarta, 1985, hlm. 63, 72, 405, 406 \& 427.

${ }^{5}$ Hilman Hadikusuma, Metode Pembuatan Kertas Kerja atau Skripsi Ilmu Hukum, Mandar Maju, Bandung, 1995, hlm. 65.

${ }^{6}$ Soerjono Soekanto \& Sri Mamudji, Penelitian Hukum Normatif (Suatu Tinjauan Singkat), Rajawali Pers, Jakarta, 2001, hlm. 13.
} 


\section{Metode Pengumpulan Data}

Oleh karena data yang dipergunakan dalam penelitian ini adalah data sekunder yang bersifat kualitatif, maka metode pengumpulan data yang dipergunakan adalah studi kepustakaan. Studi skepustakaan adalah suatu kegiatan (praktis dan teoritis) untuk mengumpulkan (inventarisasi), dan mempelajari (learning), serta memahami (reflektif, kritis dan sistematis serta logis) data yang berupa hasil pengolahan orang lain, dalam bentuk teks otoritatif (peraturan perundang-undangan, putusan hakim, traktat, kontrak, keputusan tata usaha negara, kebijakan publik, dan lainnya), literatur atau buku teks, jurnal, artikel, arsip atau dokumen, kamus, ensiklopedi dan lainnya yang bersifat publik maupun privat. Dalam penelitian tesis ini akan dilakukan studi kepustakaan terhadap buku-buku atau literatur, jurnal-jurnal asing, pendapat para sarjana, kasus-kasus hukum, serta simposium yang dilakukan para pakar hukum.

\section{E. Metode Analisis Data}

Metode analisis data yang digunakan dalam penelitian ini adalah metode kualitatif normatif. Metode kualitatif normatif ini dugunakan karena penelitian ini tidak menggunakan konsep-konsep yang diukur/dinyatakan dengan angka atau rumusan statistik. Dalam menganalisis data sekunder tersebut, penguraian data disajikan dalam bentuk kalimat yang konsisten, logis dan efektif serta sistematis sehingga memudahkan untuk interpretasi data dan konstruksi data serta pemahaman akan analisis yang dihasilkan, yaitu mencari sebab akibat dari suatu masalah dan menguraikannya secara konsisten, sistematis dan logis sesuai dengan perumusan masalah yang menjadi fokus dalam penelitian ini.

\section{HASIL PENELITIAN DAN PEMBAHASAN}

\section{A. Wujud Pelayanan Kesehatan Masyarakat Miskin Yang Ideal}

Kesehatan merupakan salah satu unsur kesejahteraan umum yang harus diwujudkan sesuai dengan cita-cita bangsa Indonesia sebagaimana dimaksud dalam Pembukaan dan Pasal 28H serta Pasal 34 Ayat (2) Undang-Undang Dasar 1945. Untuk mencapai cita-cita bangsa tersebut, maka hal ini direalisasikan melalui pembangunan Pembangunan Kesehatan yang diarahkan untuk mempertinggi derajat kesehatan sehingga diperlukan upaya yang lebih memadai bagi peningkatan derajat kesehatan dan pembinaan penyelenggaraan upaya kesehatan secara menyeluruh dan terpadu.

Dalam bahasa Indonesia dikenal kata "sehat" dan kata "kesehatan", yang masing-masing memiliki pengertian yang berbeda satu sama lainnya. Kata "sehat" menjelaskan kondisi atau keadaan dari subjek, misalnya: anak sehat, orang sehat. Sedangkan kata "kesehatan" menjelaskan tentang sifat dari subjek, misalnya kesehatan manusia, kesehatan masyarakat, kesehatan individu. Namun demikian, dalam benak orang awam sehat diartikan sebagai orang dalam kondisi tidak sakit, dapat melaksanakan kegiatan, tidak ada keluhan. ${ }^{7}$

Kata "sehat" dapat didefinisikan dengan berbagai pengertian. Organisasi Kesehatan Dunia, mendefinisikan sehat, adalah keadaan fisik, mental dan sosial yang baik dan bukan tidak terdapatnya masalah kesehatan berupa penyakit maupun kelemahan". Sementara itu, menurut batasan yang dirumuskan dalam Pasal 1 Angka (1) Undang-Undang Kesehatan, sehat adalah keadaan sejahtera dari badan, jiwa dan sosial yang memungkinkan setiap orang hidup produktif secara sosial dan ekonomi. Dari batasan diatas dapat di mengerti bahwa kesehatan mencakup empat aspek: (1) fisik (badan), (2) mental (jiwa), (3) sosial dan (4) ekonomi. Mengacu empat aspek di atas berarti kesehatan seseorang tidak hanya diukur dari aspek fisik, mental dan sosial

\footnotetext{
${ }^{7}$ Lihat Soekijo Notoatmodjo, Promosi Kesehatan (Teori dan Aplikasi), Rineka Cipta, Jakarta, 2005, hlm. 2. 
saja, tetapi juga diukur dari produktivitasnya dalam arti mempunyai pekerjaan atau menghasilkan sesuatu secara ekonomi. ${ }^{8}$

Keempat dimensi kesehatan tersebut saling mempengaruhi dalam mewujudkan tingkat kesehatan tersebut pada sesorang, kelompok atau masyarakat. Itulah sebabnya, maka kesehatan bersifat holistik atau menyeluruh yang mengandung ke empat aspek. Wujud atau indikator dari masing-masing aspek tersebut, yaitu sebagai berikut: Pertama, Kesehatan fisik terwujud apabila seseorang tidak merasa sakit atau tidak adanya keluhan dan memang secara klinis tidak hanya penyakit. Semua organ tubuh berfungsi normal atau tidak ada ganguan fungsi tubuh.

Kedua, Kesehatan mental (jiwa) mencakup 3 komponen, yakni: pikiran, emosional dan spritual. Pikiran yang sehat itu tercermin dari cara berfikir seseorang atau jalan pikiran. Jalan pikiran yang sehat apabila seseorang mampu berfikir logis (masuk akal) atau berfikir secara runtut. Emosional yang sehat tercermin dari kemampuan seseorang untuk mengekspresikan emosinya, misalnya takut, gembira, kuatir, sedih dan sebagainya. Spiritual yang sehat akan tercermin dari cara seseorang dalam mengekspresikan rasa syukur, pujian atau penyembahan, keagungan dan sebagainya terhadap sesuatu di balik alam ini, yakni Sang Pencipta Alam dan Seisinya (Allah Yang Maha Kuasa). Secara mudah, spiritual yang sehat dapat dilihat dari praktik keagamaan, keyakinan atau kepercayaan sesuai dengan agama yang dianut. Dengan perkataan lain, spiritual yang sehat adalah apabila orang melakukan ibadah dan aturan-aturan agama yang dianutnya.

Ketiga, Kesehatan sosial terwujud apabila seseorang mampu berkomunikasi dengan orang lain secara baik ataupun berinteraksi dengan orang atau kelompok lain tanpa membedakan ras, suku agama atau kepercayaan, status sosial, ekonomi, politik dan sebagainya, saling hargai dan toleransi.

Keempat, Kesehatan dari aspek ekonomi terlihat dari seseorang (dewasa) itu produktif, dalam arti mempunyai kegiatan yang menghasilkan sesuatu yang dapat menyokong secara finansial terhadap hidupnya sendiri atau keluarganya. Bagi mereka yang belum dewasa (siswa atau mahasiswa) dan usia lanjut (pensiunan), dengan sendirinya batasan ini tidak berlaku. Oleh sebab itu bagi kelompok tersebut yang berlaku adalah produktif secara sosial, yakni mempunyai kegiatan yang berguna bagi kegiatan mereka nanti, misalnya berprestasi bagi siswa atau mahasiswa dan kegiatan pelayanan sosial, pelayanan agama atau pelayanan masyarakat yang lain bagi usia lanjut. ${ }^{9}$

Kesehatan sebagaimana yang diatur dalam Undang-Undang No. 23 Tahun 1992 tentang Kesehatan (untuk selanjutnya akan disebut UU Kesehatan) di dalamnya mengandung dua aspek, yaitu "Upaya Kesehatan" dan "Sumber Daya Kesehatan". Adapun yang dimaksudkan dengan upaya kesehatan sebagaimana diatur dalam Pasal 11 UU Kesehatan adalah setiap kegiatan dan/atau serangkaian kegiatan yang dilakukan secara terpadu, terintegrasi, dan berkesinambungan untuk memelihara dan meningkatkan derajat kesehatan masyarakatdalam bentuk pencegahan penyakit, peningkatan kesehatan, pengobatan penyakit, dan pemulihan kesehatan oleh pemerintah dan/atau masyarakat. Selanjutnya dalam Pasal 47 UU Kesehatan disebutkan bahwa untuk mewujudkan derajat kesehatan yang optimal bagi masyarakat, diselenggarakan upaya kesehatan dengan pendekatan pemeliharaan, peningkatan kesehatan (promotif), pencegahan penyakit (preventif), penyembuhan penyakit (kuratif), dan pemulihan kesehatan (rehabilitatif) yang dilaksanakan secara menyeluruh, terpadu, dan berkesinambungan. Maka berdasarkan uraian tersebut di atas, dapat disimpulkan bahwa upaya kesehatan adalah setiap kegiatan yang dilakukan oleh pemerintah dan/atau swasta serta masyarakat secara terpadu dan saling mendukung, untuk memelihara dan meningkatkan kesehatan serta mencegah

\footnotetext{
${ }^{8}$ Ibid., hlm. 3 .

${ }^{9}$ Lihat Soekidjo Notoatmojo, Op. Cit., hlm. 4-6.
} 
dan menanggulangi timbulnya masalah kesehatan, guna menjamin tercapainya derajat kesehatan masyarakat yang setinggi-tingginya.

Menurut Wila Chandrawila Supriadi terdapat dua aspek dari upaya kesehatan tersebut, yakni pemeliharaan kesehatan dan pelayanan kesehatan. Istilah pemeliharaan kesehatan dipakai untuk menunjuk pada kegiatan upaya kesehatan masyarakat dan istilah pelayanan kesehatan dipakai untuk upaya kesehatan individu (dikenal juga sebagai pelayanan medis). Inti dari pemeliharaan kesehatan adalah kesehatan masyarakat (public health), menyangkut hal-hal yang berhubungan antara lain dengan pembasmian penyakit menular, usaha kesehatan lingkungan, usaha kesehatan sekolah. Arti dari pelayanan kesehatan adalah hubungan segitiga antara tenaga kesehatan, pasien dan sarana kesehatan. ${ }^{10}$

Secara de facto, istilah pelayanan kesehatan tersebut dimaknai berbeda oleh doktrin di dalam beberapa literatur, seperti misalnya pendapat yang dikemukakan oleh Lavey dan Loomba, bahwa yang dimaksud dengan pelayanan kesehatan ialah setiap upaya baik yang diselenggarakan sendiri atau bersama-sama dalam suatu organisasi untuk meningkatkan dan memelihara kesehatan, mencegah penyakit dan mengobati penyakit, serta memulihkan kesehatan yang ditujukan, baik terhadap perseorangan, kelompok ataupun masyarakat. ${ }^{11}$

Pengertian tersebut mengandung arti pelayanan kesehatan yang luas, yaitu mencakup mencakup berbagai tindakan seperti preventif, kuratif, promotif dan rehabilitatif, baik yang dilakukan oleh perseorangan maupun dalam suatu organisasi, begitupun ditujukan kepada masyarakat ataupun perseorangan. Sehingga istilah pelayanan kesehatan ini mencakup aspek pemeliharaan kesehatan dan pelayanan kesehatan sebagaimana dikemukakan oleh Wila Chandrawila Supriadi tersebut.

Adapun istilah yang menunjuk pada istilah pelayanan kesehatan sebagaimana yang dikemukakan oleh Wila Chandrawila Supriadi tersebut, di beberapa literatur disebut dengan istilah pelayanan medis. Pengertian dari istilah pelayanan medis ini menurut S. Verbogt adalah pelayanan yang diberikan secara langsung dan dapat dipertanggung jawabkan secara profesional (profesi medis), yang sasaran utamanya ditujukan kepada individu sehubungan dengan kesehatannya, baik jasmani maupun rohani dalam bentuk pengobatan dan/atau pemulihan. ${ }^{12}$ Dengan demikian istilah pelayanan medis ini dapat dimengerti sebagai pelayanan yang diberikan kepada individu sehubungan dengan kesehatannya, dalam bentuk upaya kesehatan yang sebagian besar berupa upaya kuratif atau pengobatan dan/atau pemulihan yang dilaksanakan atas dasar hubungan individual antara para profesi medis dengan individu yang membutuhkannya.

Pembangunan Kesehatan merupakan upaya untuk memenuhi salah satu hak dasar rakyat, yaitu hak untuk memperoleh pelayanan kesehatan sesuai dengan Undang-undang Dasar 1945. Untuk memenuhi salah satu hak dasar rakyat, yaitu hak untuk memperoleh pelayanan kesehatan, maka pemerintah menetapkan Pembangunan Kesehatan dalam Program Pembangunan Nasional. Salah satu Program Pembangunan Nasional seperti yang tercantum dalam Undangundang Nomor 25 Tahun 2000 tentang Program Pembangunan Nasional adalah upaya kesehatan. Tujuan umum program ini adalah meningkatkan pemerataan dan mutu upaya kesehatan yang berhasil guna dan berdaya-guna serta terjangkau oleh segenap anggota masyarakat. Sasaran umum program ini adalah tersedianya pelayanan kesehatan dasar (pelayanan kesehatan masyarakat yang dilaksanakan di puskesmas) dan rujukan (pelayanan kesehatan lanjutan yang

\footnotetext{
${ }^{10}$ Lihat Wila Chandrawila Supriadi, Aspek Perdata Pelayanan Kesehatan dalam "PRO JUSTITIA" Tahun XXII Nomor 4 Oktober 2004, FH Unpar \& Ilumni FH Unpar, Bandung, hlm. 12-14.

${ }^{11}$ Lihat Veronica Komalawati, Peranan Informed Consent dalam Transaksi Terapeutik, Citra Aditya Bakti, Bandung, 1999, hlm. 77.

${ }^{12}$ Lihat S. Verbogt, Bab-bab Hukum Kesehatan diterjemahkan oleh: F. Tengker, Nova, Bandung, Tanpa Tahun, hlm. 12.
} 
dilaksanakan di rumah sakit), baik pemerintah maupun swasta yang didukung oleh peran serta masyarakat dan sistem pembiayaan pra upaya (dana jaminan kesehatan).

Upaya untuk mendapatkan keadaan dalam arti sehat secara keseluruhan, dimulai dari upaya terhadap penyakit, sampai kepada upaya kesehatan ke arah kesatuan terhadap seluruh masyarakat dengan mengutamakan peran serta masyarakat yang mencakup, peningkatan, pencegahan, penyembuhan, dan pemulihan yang bersifat berkesinambungan dengan berbagai faktor yang dapat mempengaruhi kesehatan secara menyeluruh dan umum. Untuk meningkatkan derajat kesehatan, maka kegiatan pelayanan kesehatan dilakukan melalui upaya kesehatan.

Hal ini sebagaimana diatur dalam Pasal 1 Angka (2) Undang-undang nomor 36 tahun 2009 tentang Kesehatan, bahwa:

"Upaya kesehatan adalah setiap kegiatan untuk memelihara dan meningkatkan kesehatan".

Kemudian yang dalam Pasal 10 Undang-undang Kesehatan dinyatakan pula bahwa:

"Untuk mewujudkan derajat kesehatan yang optimal bagi masyarakat, diselenggarakan upaya kesehatan dengan pendekatan pemeliharaan peningkatan kesehatan (promotif), pencegahan penyakit (preventif), penyembuhan penyakit (kuratif), dan pemulihan kesehatan (rehabilitatif) yang dilaksanakan secara menyeluruh, terpadu, dan berkesinambungan".

Dari ketentuan Pasal 1 Angka (2) dan Pasal 10 Undang-undang nomor 36 tahun 2009 tentang Kesehatan, dapat disimpulkan bahwa upaya kesehatan adalah setiap kegiatan yang dilakukan oleh pemerintah dan atau swasta serta masyarakat secara terpadu dan saling mendukung, untuk memelihara dan meningkatkan kesehatan serta mencegah dan menanggulangi timbulnya masalah kesehatan, guna menjamin tercapainya derajat kesehatan masyarakat yang setinggi-tingginya.

\section{B. Analisis Hubungan Antara Pelayanan Kesehatan Masyarakat Miskin Melalui Program Jamkesmas Dan Pelayanan Kesehatan Masyarakat Miskin Yang Ideal}

Undang-Undang Dasar 1945 Pasal 28H dan Undang-undang nomor 36 tahun 2009 tentang Kesehatan, menetapkan bahwa setiap orang berhak mendapatkan pelayanan kesehatan. Karena itu setiap individu, keluarga dan masyarakat berhak memperoleh perlindungan terhadap kesehatannya, dan negara bertanggungjawab mengatur agar terpenuhi hak hidup sehat bagi penduduknya, termasuk bagi masyarakat miskin dan tidak mampu.

Dalam Pasal 10 UU Kesehatan disebutkan bahwa untuk mewujudkan derajat kesehatan yang optimal bagi masyarakat, diselenggarakan upaya kesehatan dengan pendekatan pemeliharaan, peningkatan kesehatan (promotif), pencegahan penyakit (preventif), penyembuhan penyakit (kuratif), dan pemulihan kesehatan (rehabilitatif) yang dilaksanakan secara menyeluruh, terpadu, dan berkesinambungan.

Menurut UU Kesehatan no 36 tahun 2009 pasal 1, yang dimaksud dengan pelayanan kesehatan promotif adalah suatu kegiatan dan/ atau serangkaian kegiatan pelayanan kesehatan yang lebig mengutamakan kegiatan yang bersifat promosi kesehatan. Pelayanan kesehatan preventif adalah suatu kegiatan pencegahan terhadap suatu masalah kesehatan/ penyakit. Pelayanan kesehatan kuratif adalah suatu kegiatan dan/ atau serangkaian kegiatan pengobatan yang ditujukan untuk penyembuhan penyakit, pengurangan penderitaan akibat penyakit, pengendalian penyakit, atau pengendalian kecacatan agar kualitas hidup penderita dapat terjaga seoptimal mungkin. Pelayanan kesehatan rehabilitatif adalah suatu kegiatan dan/ atau serangkaian kegiatan untuk mengembalikan bekas penderita ke dalam masyarakat sehingga 
dapat berfungsi lagi sebagai anggota masyarakat yang berguna untuk dirinya dan masyarakat semaksimal mungkin sesuai dengan kemampuannya.

Kedokteran pencegahan atau preventive medicine adalah ilmu dan seni mencegah penyakit, memperpanjang hidup dan meningkatkan kesehatan fisik dan mental dan efisiensi, untuk berbagai kelompok dan masyarakat oleh petugas kesehatan masyarakat, untuk perorangan dan keluarga oleh dokter umum dan dokter gigi melalui proses kegiatan perorangan dan masyarakat.

Pencegahan mengacu pada perencanaan dan pelaksanaan tindakan untuk mencegah atau menghambat kejadian kasus yang tidak diinginkan, dan oleh karenanya lebih diinginkan daripada intervensi, pelaksanaan tindakan selama kejadian berlangsung. Contoh, pelaksanaan imunisasi untuk mencegah penyakit lebih dipilih dibanding konsumsi antibiotik untuk menyembuhkan penyakit itu

Demikian juga halnya dalam Konvensi International Labour Organization (Konvensi ILO) Nomor 102 Tahun 1952 yang menganjurkan semua negara untuk memberikan perlindungan minimum kepada setiap tenaga kerja. Sejalan dengan ketentuan tersebut, Majelis Permusyawaratan Rakyat Republik Indonesia dalam ketetapan Majelis Permusyawaratan Rakyat (TAP MPR) Nomor X/ MPR/ 2001 menugaskan Presiden untuk membentuk Sistem Jaminan Sosial Nasional dalam rangka memberikan perlindungan sosial yang menyeluruh dan terpadu.

Pembentukan Sistem Jaminan Sosial Nasional, direalisasikan melalui Undang-Undang Nomor 40 Tahun 2004 tentang Sistem Jaminan Sosial Nasional (UU SJSN) yang mempunyai program jaminan kesehatan, jaminan kecelakaan kerja, jaminan hari tua, jaminan pensiun dan jaminan kematian. Jaminan sosial ini merupakan upaya pemerintah dalam menangani krisis moneter. Sebagaimana diketahui krisis dimulai sejak tahun 1997 sampai sekarang, disebabkan oleh faktor multidimensi di antaranya pengalihan program subsidi bagi masyarakat miskin berupa subsidi Bahan Bakar Minyak (BBM) untuk sektor kesehatan bagi masyarakat miskin menjadi program Jaring Pengaman Kesehatan bagi Masyarakat Miskin (JPK-MM).

Kebutuhan pokok minimal, salah satunya adalah kesehatan, yang semakin sulit didapat bagi sebagian warga, terutama warga miskin, harus diupayakan dicapai oleh pemerintah dengan berbagai cara. Salah satu upaya yakni dengan program asuransi sosial bagi masyarakat miskin. Dalam program ini masyarakat miskin akan didata terlebih dahulu degan beberapa kriteria yang telah ditentukan sebelumnya agar terdapat keseragaman dalam melaksanakan pendataan tersebut. Pada pelaksanaannya pendataan yang dihasilkan tidak seperti yang diharapkan sebelumnya karena berbagai kendala. Kendala yang dimaksud antara lain kriteria yang menjadi acuan tidak terlalu jelas batasan yang menjadi acuan bagi para pendata, sehingga terkesan pendataannya seperti tidak tepat sasaran. Selain itu kondisi geografi yang tidak sama antara satu daerah dengan daerah lainnya. Ada daerah yang sulit untuk dijangkau sehingga pendataan tidak sampai sasaran. Faktor ekonomi yang tidak kunjung membaik, hal ini tampak dari laporan Bank Dunia yang memperhitungkan 108,78 juta orang atau 49 persen dari total penduduk Indonesia dalam kondisi miskin dan rentan menjadi miskin.

Sebagaimana diketahui kesehatan adalah hak setiap individu tanpa membeda-bedakan yang mampu maupun yang tidak mampu. Oleh karena itu menjadi tugas negara untuk menyediakan segala fasilitas yang diperlukan agar rakyatnya tetap sehat sehingga sudah sewajarnya kesehatan mendapatkan subsidi yang besar. Sebab pada dasarnya kesehatan merupakan sebuah investasi sehingga patut mendapat perhatian dari pemerintah. Bila rakyat suatu negara sehat maka pembangunan dalam berbagai bidang dapat dilaksanakan secara optimal. 
Untuk mendapatkan pelayanan kesehatan bagi masyarakat miskin yang diselenggarakan melalui program Jamkesmas tersebut, maka ada beberapa syarat atau kriteria yang harus dipenuhi, namun perlu juga dikemukakan di sini bahwa ada pelayanan kesehatan yang tidak ditanggung oleh PT Askes, seperti untuk general check up, prothesis gigi tiruan, kosmetika, pengobatan alternative, penunjang diagnosa canggih, kecuali untuk penyelamatan jiwa (life saving), serta infertilitas.

Adanya keterbatasan pelayanan kesehatan membawa dampak bagi warga miskin yakni rentan terhadap berbagai macam penyakit, karena pada umumnya golongan masyarakat ini mempunyai gizi buruk, pengetahuan tentang kesehatan kurang, perilaku kesehatan kurang, lingkungan pemukiman buruk, biaya kesehatan tidak tersedia serta kurang mendapat akses informasi kesehatan.

Pada hakekatnya pelayanan terhadap masyarakat miskin menjadi tanggung jawab dan dilaksanakan bersama oleh pemerintah pusat dan pemerintah daerah, pemerintah propinsi/kabupaten/kota berkewajiban memberi kontribus sehinga menghasilkan pelayanan yang optimal. Untuk itulah Jamkesmas ini diselenggarakan.

Jamkesmas adalah program bantuan sosial untuk pelayanan kesehatan bagi masyarakat miskin dan tidak mampu. Program ini diselenggarakan secara nasional agar terjadi subsidi silang dalam rangka mewujudkan pelayanan kesehatan yang menyeluruh bagi masyarakat miskin.

Untuk itu pada tahun 2004, dengan mengacu kepada UU Sistem Jaminan Sosial Nasional diselenggarakanlah Aseskin sebagai jaminan pemeliharaan kesehatan masyarakat miskin, yang kemudian pada tahun 2008 yang lalu program tersebut berganti menjadi Jamkesmas sebagaimana diatur dalam S.K. Menkes No. 125 Tahun 2008 tentang Pedoman Pelaksanaan Program Jamkesmas Tahun 2008.

Namun program Jamkesmas pada prakteknya tidak meliputi perlindungan di bidang promotif dan preventif dan ada pembatasan di bidang kuratif dan rehabilitatif sedangkan kriteria pelayanan kesehatan yang ideal berdasarkan UU Kesehatan tahun 2009 pasal 47 adalah meliputi bidang promotif, preventif, kuratif, dan rehabilitatif.

Adanya keterbatasan pelayanan kesehatan membawa dampak bagi warga miskin yakni rentan terhadap berbagai macam penyakit, karena pada umumnya golongan masyarakat ini mempunyai gizi buruk, pengetahuan tentang kesehatan kurang, perilaku kesehatan kurang, lingkungan pemukiman buruk, biaya kesehatan tidak tersedia serta kurang mendapat akses informasi kesehatan.

Tidak adanya perlindungan di bidang promotif dan preventif serta terdapatnya pembatasan-pembatasan pelayanan di bidang kuratif dan rehabilitatif yang diterapkan dalam penyelenggaraan program Jamkesmas ini (misalnya pembatasan biaya kaca mata, alat bantu dengar, tongkat/alat bantu berjalan bagi mereka yang lumpuh) menyebabkan pelayanan kepada mereka yang membutuhkan sekali alat bantu tersebut menjadi terhambat. Selain itu di bidang rehabilitatif (pemulihan kesehatan), seperti pemeriksaan pasca pengobatan, tidak ditanggung dalam program Jamkesmas. Disamping pembatasan masih ada lagi jenis pelayanan yang tidak ditanggung sama sekali oleh program Jamkesmas ini seperti untuk general check up, prothesis gigi tiruan, kosmetika, pengobatan alternative, penunjang diagnosa canggih, kecuali untuk penyelamatan jiwa (life saving), serta infertilitas sebagaimana tercantum dalam S.K. Menkes No. 125 Tahun 2008 tentang Pedoman Pelaksanaan Program Jamkesmas Tahun 2008 tersebut. Dengan demikian berdasarkan uraian analisis hubungan antara pola pelayanan kesehatan melalui program JAMKESMAS yang dilaksanakan saat ini dan penanggulangan masalah kesehatan bagi masyarakat miskin yang dalam hal ini adalah berupa terwujudnya pelayanan kesehatan masyarakat miskin yang ideal tersebut di atas, dapat ditarik kesimpulan yakni bahwa pelaksanaa pelayanan kesehatan masyarakat miskin melalui program Jamkesmas 2008 sebagaimana 
tercantum dalam S.K. Menkes No. 125 Tahun 2008 tentang Pedoman Pelaksanaan Program Jamkesmas Tahun 2008 menyebabkan dilanggarnya hak masyarakat miskin untuk hidup sehat, karena pedoman pelaksanaan Jamkesmas tersebut di dalamnya terdapat beberapa pembatasan pelayanan kesehatan dan terdapat pula pelayanan kesehatan masyarakat miskin yang tidak dijamin oleh program Jamkesmas. Padahal pelayanan kesehatan yang dibatasi dan pelayanan kesehatan masyarakat miskin yang tidak dijamin oleh program Jamkesmas tersebut itu merupakan pelayanan kesehatan yang termasuk ke dalam upaya kesehatan sebagaimana yang diamanatkan oleh UU Kesehatan.

\section{KESIMPULAN DAN SARAN}

\section{A. Kesimpulan}

1. Wujud pelayanan kesehatan masyarakat miskin yang ideal merujuk pada kriteria derajat kesehatan yang optimal bagi masyarakat berdasarkan Pasal 47 UU Kesehatan tahun 2009, dimana diselenggarakan upaya kesehatan dengan pendekatan pemeliharaan, peningkatan kesehatan (promotif), pencegahan penyakit (preventif), penyembuhan penyakit (kuratif), pemulihan kesehatan (rehabilitatif) yang dilaksanakan secara menyeluruh, terpadu, dan berkesinambungan.

2. Dengan terdapatnya pembatasan-pembatasan dalam pelayanan kesehatan maka pelaksanaan pelayanan kesehatan masyarakat miskin melalui program Jamkesmas 2008 sebagaimana tercantum dalam S.K. Menkes No. 125 Tahun 2008 tentang Pedoman Pelaksanaan Program Jamkesmas Tahun 2008 menyebabkan dilanggarnya hak masyarakat miskin untuk hidup sehat

\section{B. Saran}

1. Perlu dilakukan perubahan secara signifikan terhadap pedoman pelaksanaan program Jamkesmas peningkatan pelayanan kesehatan di bidang promotif dan preventif (selain di bidang kuratif dan rehabilitatif) agar masyarakat mendapatkan derajat kesehatan yang ideal.

2. Diperlukan penambahan subsidi dari pemerintah di bidang kesehatan khususnya dalam program Jamkesmas agar program Jamkesmas dapat berjalan dengan baik.

\section{DAFTAR PUSTAKA}

\section{BUKU}

Agnes Widanti. S., 2005, Petunjuk Penulisan Usulan Penelitian dan Tesis, Penerbit Unika Soegijapranata, Semarang.

Agnes Widanti. S., A. Joko Purwoko, Hermawan Pancasiwi (Editor), 2005, Refleksi $\quad$ Hukum dalam Masyarakat, Penerbit Unika Soegijapranata, Semarang.

ARRIME, 2002, Pedoman manajemen Puskesmas, Departemen Kesehatan, Jakarta.

A.Muchaddam Fahham, Perlindungan Sosial dalam "Info Singkat Kesejahteraan Sosial” Vol I, Maret 2009, Sekjen DPR RI, hlm. 2.

Edi Suharto, Membangun Masyarakat Memberdayakan Rakyat: Kajian Strategis Pembangunan Kesejahteraan Sosial dan Pekerja Sosial, RefikaAditama, Bandung, 2005, hlm. 40-41.

Hasbullah Thabrany, 2005, Asuransi Kesehatan Nasional, Edisi Baru, Penerbit Pusat Kajian Ekonomi Kesehatan FKM-UI, Jakarta.

Kansil, C.S.T., 1981, Pancasila dan Undang-Undang Dasar 1945, Penerbit Pradnya Paramita, Jakarta.

Kansil, C.S.T., 2002, Pengantar Ilmu Hukum Jilid I, Penerbit Balai Pustaka, Jakarta. 
Kansil, C.S.T., 2003, Pengantar Ilmu Hukum Jilid II, Penerbit Balai Pustaka, Jakarta.

Kamus Besar Bahasa Indonesia, 2001, Edisi Ketiga, Departemen Pendidikan $\quad$ Nasional, Jakarta.

Man Suparman Sastrawidjaja, 2005, Aspek-aspek Hukum Asuransi dan Surat Berharga, Penerbit P.T. ALUMNI, Bandung

Masyhur Effendi, A. 2005, Perkembangan Dimensi Hak Asasi Manusia (HAM) dan Proses Dinamika Penysunsn Hak Asasi Manusia (HAKHAM), Cetakan Pertama, Penerbit Ghalia Indonesia, Bogor.

Moh. Nazir, 2003, Metode Penelitian, Penerbit Ghalia Indonesia, Jakarta.

Muladi, 2005, Hak Asasi Manusia (HAM) Hakekat, Konsep dan Implikasi dalam Perspektif Hukum Masyarakat, Penerbit PT Refika Aditama, Bandung.

Philipus M. Hadjon, et al, 1993, Pengantar Hukum Administrasi Indonesia, Cetakan kedua, Penerbit Gadjah Mada University Press, Jogyakarta.

Petunjuk Penulisan usulan Penelitian dan Tesis. Penerbit UNIKA Soegipranata, Semarang, 2005.

Pedoman Kerja Puskesmas, Jilid I, 1999, Departemen Kesehatan, Jakarta.

Sistem Jaminan Sosial Nasional. Penerbit CV. Nuansa Aulia, Bandung, 2006.

Veronica Komalawati, Peranan Informed Consent dalam Transaksi Terapeutik, Citra Aditya Bakti, Bandung, 1999, hlm. 77.

Yaslis Ilyas, Mengenai Asuransi Kesehatan, Penerbit Fakultas Kesehatan Masyarakat UI, Jakarta, 2003, Cet Pertama, hal 166.

Departemen Kesehatan RI, 2002, ARRIME Pedoman manajemen Puskesmas, Departemen Kesehatan, Jakarta.

Departemen Kesehatan RI, 2004, Sistem Kesehatan Nasional, Jakarta

\section{PERUNDANG-UNDANGAN}

Undang-undang Nomor 23 Tahun 1992 tentang Kesehatan.

Undang-undang tentang Pengadilan HAM 2000 dan Undang-undang Nomor 33 Tahun 1999 tentang Hak asasi Manusia, 2001, Penerbit Citra Umbara, Bandung.

Undang-undang Nomor 40 Tahun 2004 tentang Sistem Jaminan Sosial Nasional, 2005, Cetakan pertama, Penerbit Sinar Grafika, Jakarta.

S.K. Menkes No. 125 Tahun 2008 tentang Pedoman Pelaksanaan Program Jamkesmas Tahun 2008

Keputusan Menteri Kesehatan RI Nomor 56/MENKES/SK/I/2005 tentang Penyelenggaraan Program Jaminan Pemeliharaan Kesehatan Masyarakat Miskin Tahun 2005.

Keputusan Menteri Kesehatan Republik Indonesia Nomor 1330/ Menkes/ SK/ IX/ 2005 tentang Pedoman Pelaksanaan Pelayanan Kesehatan di Puskesmas, Rujukan Rawat Jalan dan Rawat Inap Kelas III Rumah Sakit Yang Dijamin Pemerintah.

Keputusan Menteri Kesehatan RI Nomor 1241/ Menkes/ SK/ XI/ 2004 tentang Penugasan PT. Askes (Persero) dalam Pengelolaan Program Kesehatan bagi Masyarakat Miskin.

Keputusan Menteri Negara BUMN RI Nomor S-697/ MBU/2004, tentang Penugasan PT. Askes (Persero) dalam Pengelolaan Program Pemeliharaan Kesehatan bagi Masyarakat Miskin. 